\title{
FURTHER STUDIES OF THE BIOECOLOGY OF THE NEW ENGLAND TINGIDAE (HETEROPTERA) ${ }^{1}$
}

\author{
By Norman S. Bailey \\ Bradford Junior College
}

\section{A. Terrain and Vegetation}

\section{INTRODUCTION}

Seasonal population trends for three species of Corythucha were followed by regular observations and timed collections made from their respective host plants at selected stations on an undeveloped tract of land belonging to Bradford Junior College. A rather full description of the vegetation and terrain is included here to serve as a reference to the general environmental features of these lace bug habitats and their surroundings during the period of these studies. The seasonal activities of the lace bugs were followed from April until October in 1957, 1958, and 1960.

An estimate made from a plan drawn by the city engineer (Haverhill, Massachusetts) indicates that approximately ten acres are included in the study area. Our college residence is located near the southwestern corner of this property, making the area exceptionally convenient for these studies. The land is generally low and poorly drained, despite a series of open ditches that have obviously been neglected for years. More than half of the land lies between $13 \mathrm{O}^{\prime}$ and $135^{\prime}$ elevation, with a low point at $125^{\prime}$, where two of the ditches converge near the east corner of the tract and a high of $144^{\prime}$ above sea level on the west corner of our house lot. Because of the poor drainage, much of the land is swampy and in spring (or later in wet seasons) the water table is at, or even above, the ground surface wherever the elevation is below $132^{\prime}$. Within these narrow limits, the surface is somewhat irregular with a general east-southeast slope which determines the direction of the drainage.

Northeast of the study area a natural boundary, forty to fifty feet wide, is provided by a belt of mature trees. Beyond this narrow stand lies the open college athletic field. Roughly half of the field is wellcared for turf and the southeastern part supports various grasses with a scattered assortment of other herbs. This portion is usually cut over once or twice annually. The band of trees consists mostly

\footnotetext{
${ }^{1}$ Acknowledgment is gratefully made of a Sigma Xi-Resa Research Fund Grant and Grant No. G5477 from the National Science Foundation, which made this series of studies possible.
}

Manuscript received by the editor October 19, 1963. 
of oaks. White oaks predominate in the central portion where the elevation is between $13 \mathrm{I}^{\prime}$ and $\mathrm{I} 32^{\prime}$. Both to the northwest and to the southeast the land rises a little and black oaks replace the white oaks. Among the oaks some red maples, a few young elms, and such small trees as Betula populifolia Marshall, Populus tremuloides Michaux, Prunus serotina Ehrhart occur. Although undergrowth is sparse except under the white oaks where Viburnum dentatum L. grows lushly, such shrubs as Vaccinium corymbosum L., Amelanchier, an occasional Cornus, some Rhus radicans L., Vaccinium angustifolium Aiton, and Gaultheria procumbens L., along with a variety of herbaceous plants, provide some cover.

Southeast of the playing field and of the study area is a fairly extensive wooded tract. This mixed stand of hardwoods shows evidence of blow downs and fire damage. As a result, the stand is somewhat open above and a dense undergrowth of suckers and shrubs has been encouraged. Near the eastern corner of the study area is a fairly dense stand of gray birch and alders which merges with the woodland to the east and with a swampy area on the south. This small swamp spreads irregularly somewhat to the northwest. Through it runs the shallow brook that drains the tract. Much of the summer the black muck of its bed is exposed, but during the wetter seasons there is usually at least a trickle of water flowing along its course in an east-southeasterly direction.

South of the brook and swamp there is a gradual rise with patches of blackberries (Rubus) and scattered clumps of shrubby oak and wild black cherry suckers with intermingled patches of rank herbs, grasses, and even occasional areas carpeted with Danthonia and Polytrichum or other low-growing mosses. This rather open, shrubby growth merges with a denser cover of young hardwoods along the property boundary until such growth yields to the open lawn of a houselot on the south-southeast margin which bounds on that side a fairly level field on that corner of the college property. The field serves the neighborhood children as a playground and lies a few feet below the level of the road (Hyatt Avenue) which bounds the college tract on the south-southwest. On the west a ditch bounds this field and beyond it is a wild growth of naturalized garden roses, shrubs, and herbs mixed with native plants. Further west the land rises to road level and the site of a levelled house has groups of trees iricluding Acer negundo L., Juglans cinerea L., neglected apples, pears, with broken fields between. Just beyond is our house which is surrounded by trees and lawn areas. Behind (or north) of these roadside conditions is a marshy field with rank grasses that merges 
west and north with a red maple - alder swamp which follows along the ditches towards the northwest and in part joins the swamp on the northeast. South and west of the dense young red maple growth and west of our house lie relatively large and open fields with some scattered clumps of alders and highbush blueberries. Along the west-northwest, private homes in a single row buffer this tract from a busy city thoroughfare (Kingsbury Avenue). Their back yards are hedged by wild shrubs and trees of species already noted. These bound the extensive fields just mentioned.

This is obviously a city area, presently (and for an extended period) much influenced by impinging humanity in a diversity of ways. Grass fires have been occasional and to reduce this hazard, the college has had the more open areas cut over with a heavy tractor-drawn rotary mower at irregular intervals. This has been frequent enough to maintain the fields and to set back the establishment of highbush blueberries and other woody plants. The normal ecological sequence is more or less continually interrupted tending to maintain conditions of constant change within rather narrow limits. Several mowing operations took place during the period of these studies without any apparent influence on the Tingid populations under observation. Thamnophilous species may actually benefit from the mowing since it slows the establishment of trees which would otherwise ultimately crowd out their host plants.

The negative results of two methods of collecting not previously recorded for Tingids deserve brief mention.

A light trap using a 60 watt incandescent bulb was hung about 9 feet high in an Ash-leaved Maple (Acer negundo L.) which grows on the edge of the lace bug study area and nearly roo feet behind (N.E., i.e.) the garage. Lower limbs were trimmed from the tree and the light was visible for a considerable distance in all but the S.W. direction, which was unimportant because of the garage and grounds around the house. Several species of lace bugs (at least six) occur nearby. Alders, host of Corythucha pergandei Heidemann, grow under the branch tips of the maple and Alnus Station I was only about $\mathrm{IOO}^{\prime}$ to the east. The light was operated one or two full nights each week. Usually an evening that promised to be seasonably warm was intentionally chosen. The insects captured were mostly moths, beetles, and Homoptera (mainly leaf hoppers). As anticipated, no lace bugs were attracted. The most spectacular catch was a young catbird that was released unharmed.

In another maple a few yards to the north, three Japanese beetletype traps were hung about $6-8$ feet from the ground. These traps, 
and the light trap as well, were provided with circular metal hoods ( $14^{\prime \prime}$ in diameter) from bird feeders to keep the rain out. The hoods were very effective with the bait traps. Of the three, one was continuously supplied with the commercial Japanese beetle bait (geraniol), in one no bait was used, and in the third the substances listed below were used, usually for a week at a time. These traps were run from late July until mid-September or during the period when the lace bugs were assumed to be moving from overcrowded hosts to others and into the period when many were expected to be seeking hibernation sites. In spite of the fact that alders within a few feet of these traps were infested, only one lace bug turned up in the trap catches. The substances used were amyl acetate, amyl alcohol, orange oil, oil of thyme, oil of peppermint, methyl salicylate, saturate sugar solution, and molasses.

\section{B. Environmental Conditions}

During the 1958 and 1960 seasons, daily maximum and minimum temperatures were recorded and rainfall records were kept. In 1958 an attempt was made to take light readings at 9:00 a.m., 12:00 noon, and 3:00 p.m. Eastern Standard Time.

For a variety of reasons, fifty-six out of a total of 552 readings between April I 5th and October I 5th were missed ... roughly I0\%. Even if the light readings had all been taken, however, they would have little measurable significance. On a few occasions, for example, I actually recorded a variation of as much as 4500 foot candles in light readings taken just seconds apart. On the usual somewhat cloudy days in New England, this would be the expected situation. Consequently, without equipment for continuous recording of light intensities from dawn to dark, no critical evaluation can be satisfactorily determined. Furthermore, daily temperatures and rainfall records together serve as a good index of conditions controlling plant growth and incidentally, therefore, of conditions controlling the activities of such strictly phytophagous insects as the lace bugs. Temperature and rainfall data are, therefore, recorded graphically and any correlations between the tingid population cycles and such environmental factors will be evident.

The Taylor maximum-minimum thermometer was attached to a board and protected from the sides and from the top by masonite shields. Thus sheltered, it was mounted about 6 feet high on the trunk of a Mulberry tree (Morus alba L.) behind the house. Because of the buildings and several large trees nearby, the temperatures recorded were probably less extreme than they might have been 


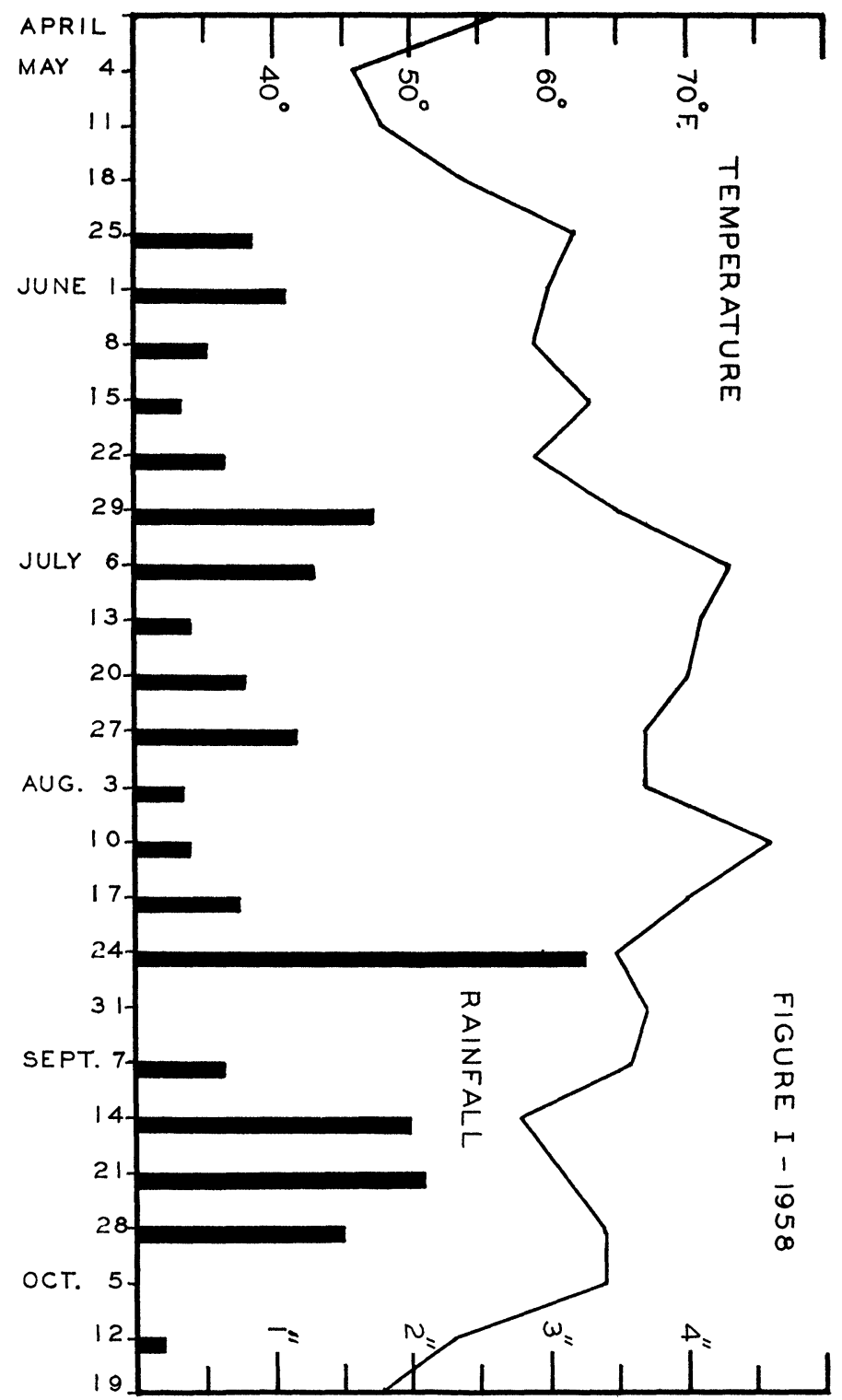


in an open spot. The daytime high was a bit lower because of the shade and the night low somewhat higher because of the sheltering trees and buildings. Nevertheless, they are satisfactorily representative for the area and agreed reasonably well with those broadcast on the local weather reports.

The Victor rain gauge was mounted according to directions in an open area about $5^{\prime}$ high on a $4 \times 4$ post facing about due north. During both 1958 and 1960 , the precipitation in the summer months was adequate and distributed sufficiently for the maintenance of plant growth. The gauge is evidently accurate since my readings on several occasions agreed with those announced by our local radio weatherman. The gauge was set up for operation on May 20, 1958. From then on daily records were kept throughout the two seasons without interruption. However, from August I4 to September I9, I 958 the aluminum cup that catches the rain disappeared and 37 days elapsed before another could be obtained. Therefore, the amount of rain collected during this interval was appreciably less due to the smaller diameter of the tube. Nevertheless, it was possible to compute approximate amounts for this period since I could compare the amount the gauge took without the catch cup with the amount reported locally for particular storms. This proved to be two-fifths on the few occasions checked and is considered sufficiently correct for this purpose.

The bar graphs in Figures I and II represent the total rainfall plotted on a weekly basis for the two seasons indicated. Maximum and minimum daily temperatures were averaged and also plotted on a weekly basis to give the temperature ranges shown in the same figures.

For ease of comparison, the same collecting technique described for population studies of Corythucha cydoniae (Fitch) and C. pruni O. \& D. was again employed (Bailey, I95 I, p. 78). This involved the use of small vials . . 45 $\mathrm{mm}$. deep and Io $\mathrm{mm}$. in diameter at the top opening ... with plastic caps. Each vial was partially filled with alcohol and could be easily held against the leaf of the host piant while the lace bugs were flicked into it with a finger tip. Collecting time was limited to five minutes and labels with pertinent data were enclosed with each collection as it was made. Some of the

EXPLANATION OF Figures I AND II

The bar graphs represent total weekly rainfall in inches with the seasonal distribution indicated below. The curves above show maximum and minimum daily temperatures averaged and plotted on the same weekly basis for the period of lace bug activity during 1958 and 1960 respectively. 


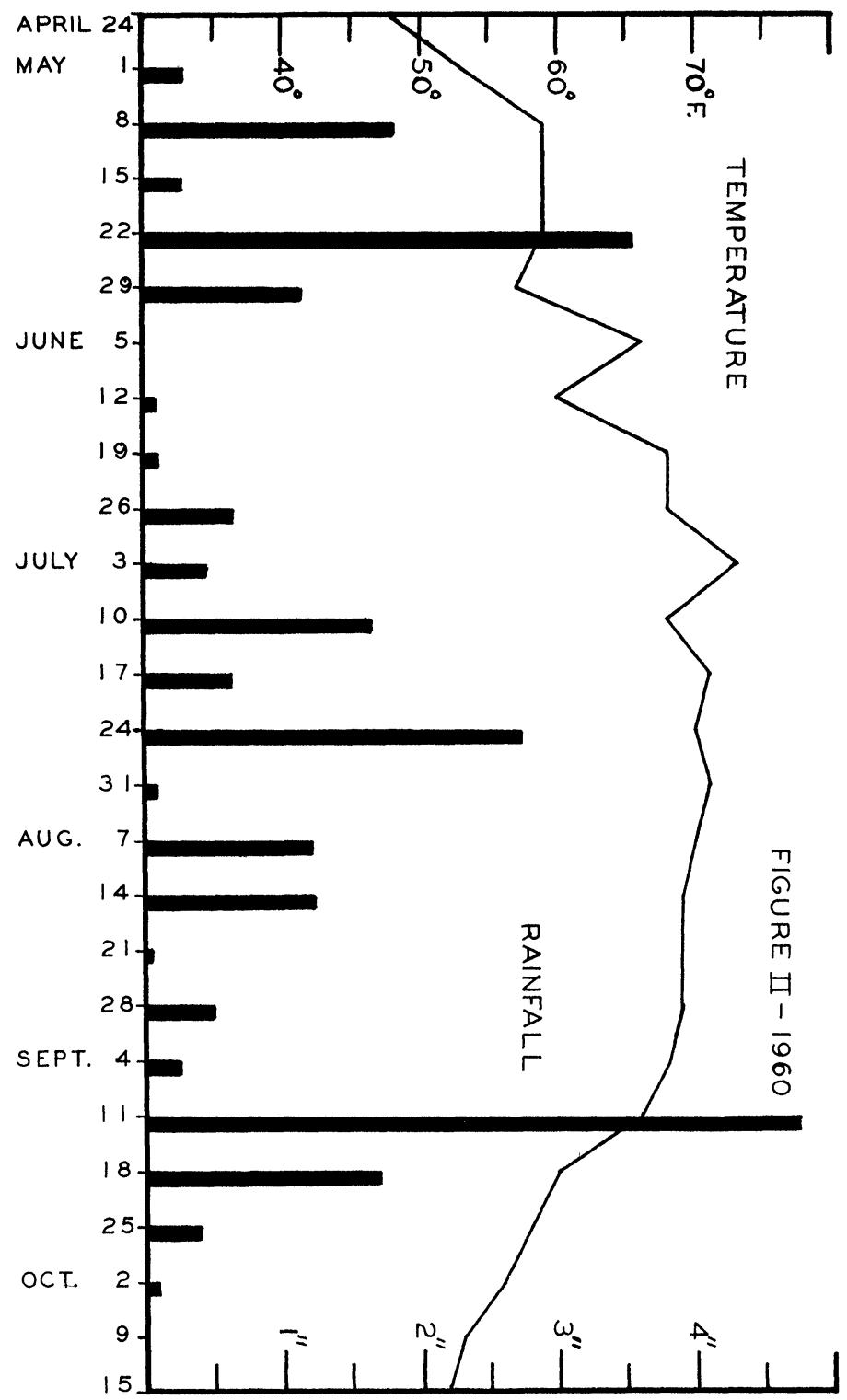


limitations of this method were suggested in the report cited above. On the whole it gives very satisfactory results for these relatively sedentary arboreal and thamnophilous species when at least modcrately abundant. When the host plant is small or the lace bug population somewhat sparse, the attrition from collecting alone could undoubtedly influence seasonal trends. Throughout the period of these studies there is no evidence that this was a significant factor.

During the 1957 season, pilot studies were made in the area described above to determine the number of species of Tingidae present and to tentatively locate host plant stations supporting sizeable lace bug populations. This initial survey revealed at least ten resident species. Of these, seven were in the genus Corythucha and one each in the genera Corythaica, Acalypta, and Leptopharsa. Collections were made at approximately weekly intervals. At the end of the season analysis of the field work indicated profitable population studies could be made for Corythucha juglandis (Fitch), C. mollicula O. \& D., and $C$. pergandei Heidemann. These studies were, therefore, continued during 1958 and 1960. In the course of this work other observations were made and will be reported.

\section{SEASONAL POPULATION TRENDS \\ and Other Notes Concerning the Willow Lace Bug (Corythucha mollicula Osborn and Drake)}

Among the stations chosen as a result of the 1957 survey was a shrubby clump of Salix growing on the northeastern edge of the swamp and only five or six yards from the shelter belt of trees described above. This clump of willows is about $10^{\prime}$ tall and is surrounded by other willows, trembling aspens, young oaks and elms, gray birch, alders (some appreciably taller) with a lush undergrowth of such shrubs as wild roses, Spiraea, and Viburnum species, while such ferns as the Sensitive, Royal, Cinnamon, and Interrupted along with Iris versicolor L. and sedges grow rankly amongst them. On the edge of the woods the vegetation changes to include Pteridium, Lysimachia, along with various sedges, grasses, a small tangle of Smilax herbacea L. and other herbs which form a generally more open ground cover.

The host selected supported fair numbers of $C$. mollicula in 1957 and collections were started on May 2ist. Such collections were made fairly regularly in 1957, but not strictly at weekly intervals as in I958 and 1960. In 1957 no specimens were taken after August 20th.

Two observations made in 1957 were essentially confirmed by the field studies of subsequent seasons. First, although shrubby willows 
are common in the area, this particular plant was the only one found supporting a fair population of lace bugs continuously. Actually, after collecting more or less intensively there for five summers, I have discovered $C$. mollicula on only one or two other willow clumps located about I 50 yards west of the chosen station. Although I collected this species in the area on several occasions, they were never sufficiently numerous on any other willow to serve my purpose.

Secondly, of the five tingid species that I have studied in this manner and others noted in the literature, $C$. mollicula has the shortest period of seasonal activity. Most of them disappear from the Salix by mid-August or even late July (note Figure V for 1960 season). C. pergandei Heidemann and other species may be collected on their respective hosts until late September or even into early October in favorable years. So far I have been unable to account for this. If $C$. mollicula hibernate early, I have yet to locate them. If they migrate to other willows (or another host species), I have yet to find the evidence. In 1958 ten adults were taken on their host on May IIth and a single specimen was found on September 7th, although none had been seen since August 3rd.

Since the figures are largely self-explanatory, comment will be minimal. Overwintering adults emerge from hibernation as soon as leaf development favors feeding. Usually by mid-May temperatures have made this possible. However, in some years (1957 graph) the peak may not occur until June. Graphs for the three years plainly reveal seasonal differences that largely reflect weather conditions. Maturation of the annual brood may show a peak as early as midJune (I960 graph) . . . or possibly early July is more usual. From then on the number of adults taken tends to decline, often somewhat irregularly, until by early August (or early September at the latest) no more are found. Since eggs are laid over a period of several

\section{Explanation OF Figures III, IV, and V}

These figures present graphically the population trends for Corythucha mollicula Osborn and Drake for each of the years specified. The curves are based on the actual numbers (indicated on the left) of adult lace bugs collected on the dates given below. The uppermost curve represents the totals of all population samples for the season. Differences in the seasonal distribution of females and of males in these same collections are shown by the middle and the lowermost graphs respectively.

Hibernating adults emerge from early to late May depending on the weather and temperature which also largely determine host plant leaf development. Maturation of the annual brood begins by early or . . . perhaps more commonly ... by late June, depending on the same environmental conditions. By late July or, apparently less frequently, by early September (Figure IV) the host plant has been deserted for the year. 


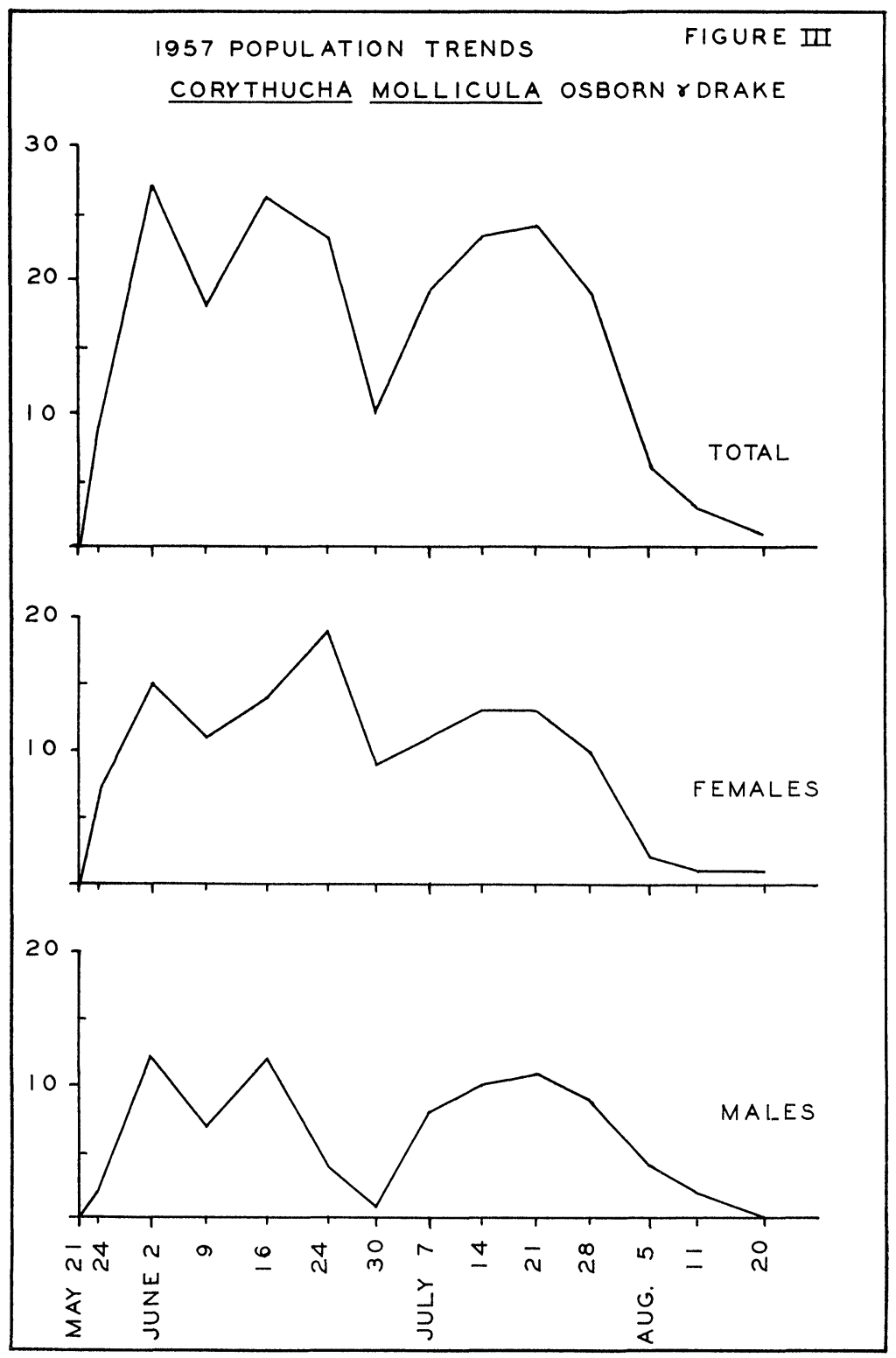




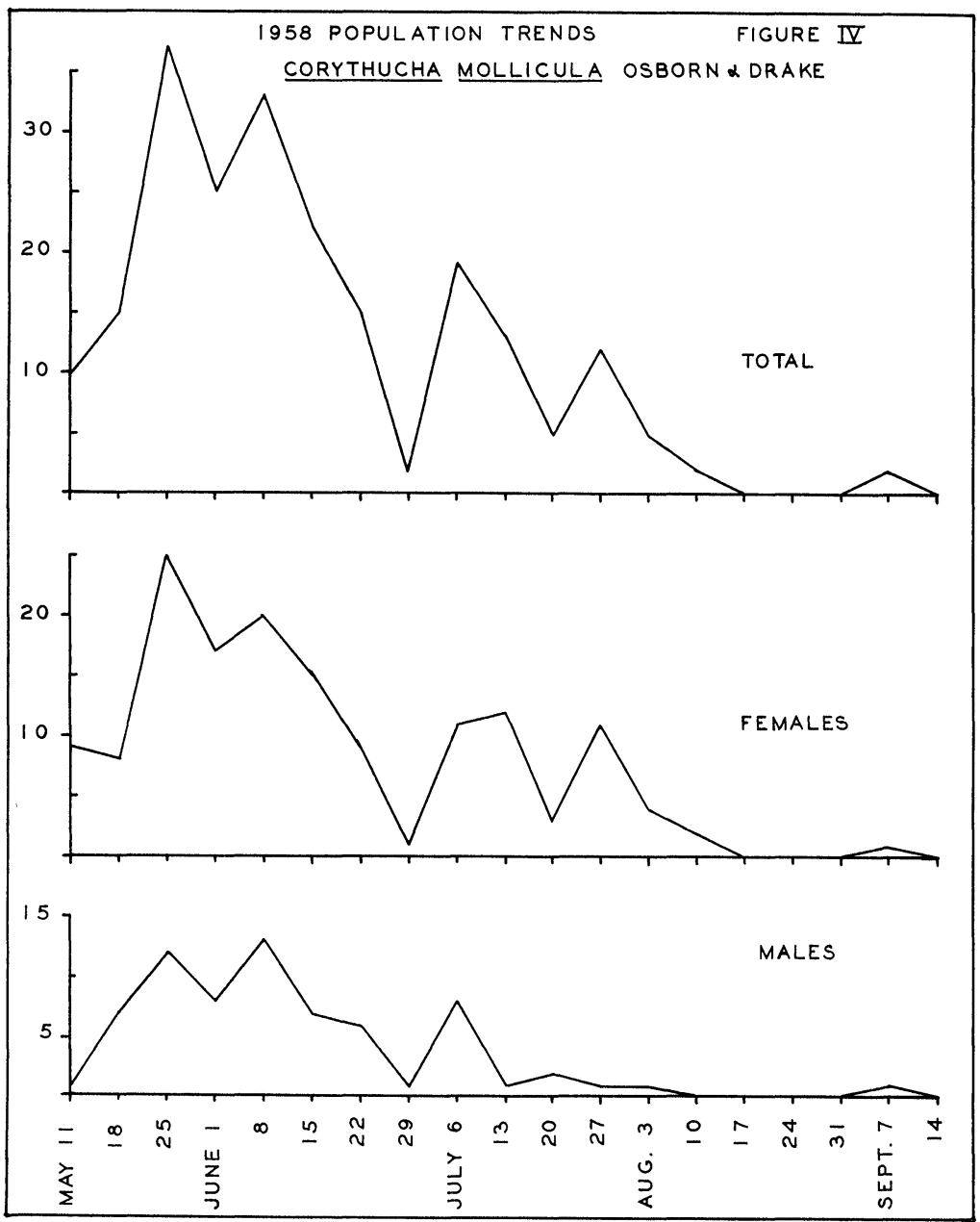




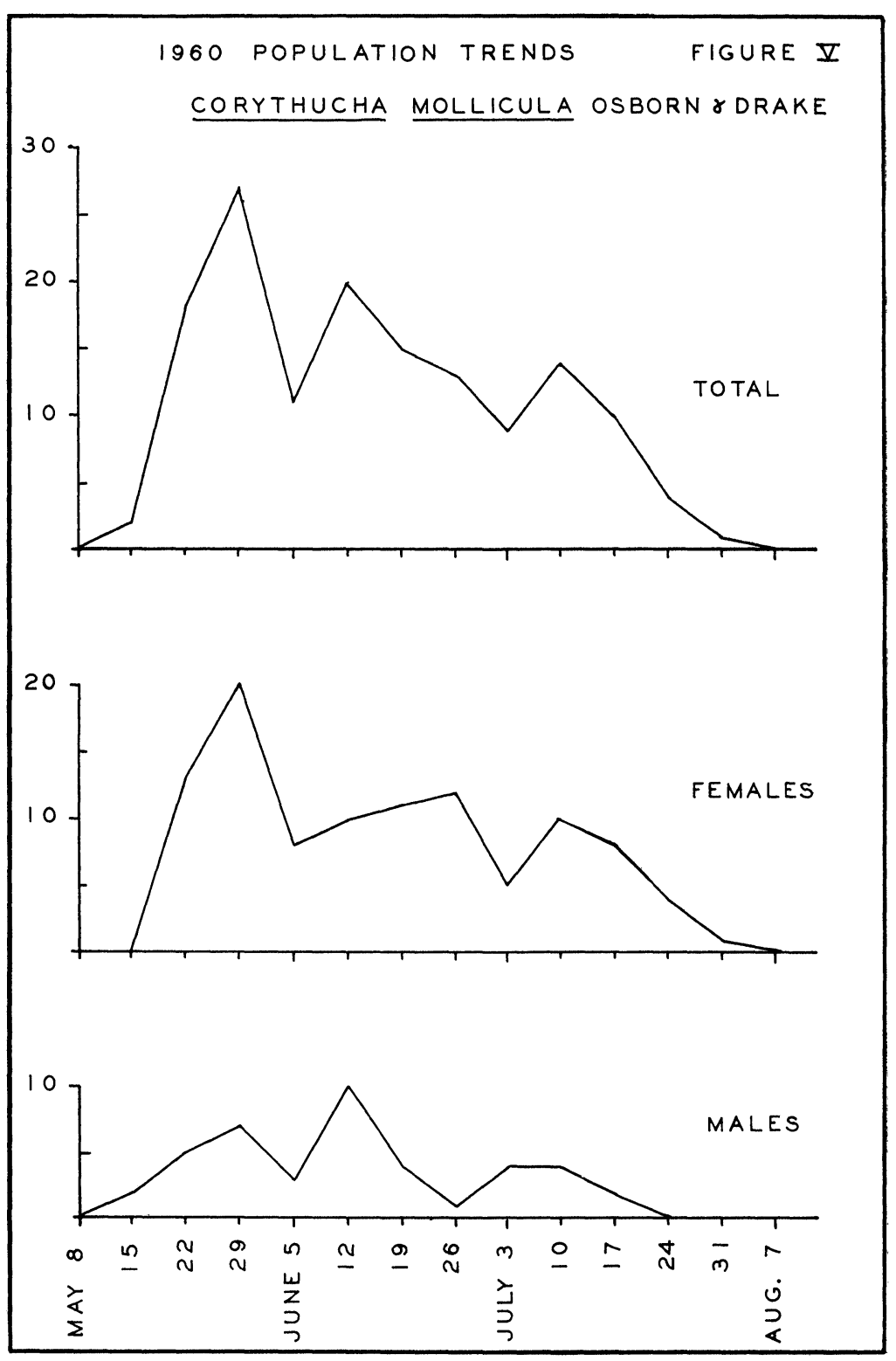


weeks, and since environmental factors regulate the time of incubation as well as the rate of nymphal development, there is a prolonged period during mid-summer when various nymphal instars may be found together and along with teneral adults. Nymphs were recorded from June 16 to August 20th in 1957.

Another notable detail is the fact that unlike $C$. cydoniae (Fitch) and $C$. pruni O. \& D. (Bailey, I95I), the C. mollicula population yielded 349 오 and $\mathrm{I} 7 \mathrm{I} \mathrm{O}^{\pi} \mathrm{O}^{\pi}$ for the three seasons, giving a ratio of slightly more than 2 to $I$ in favor of the females.

Since the eggs of $C$. mollicula O. \& D. have not been described the following data are provided. The preserved (ethyl alcohol) eggs of this species are approximately $.6 \mathrm{~mm}$. long by $.2 \mathrm{~mm}$. in diameter at the central bulge. They taper towards the rounded basal ends that are barely inserted into shallow, narrow, elliptical incisions which the females make in the tissues of the lower leaf surface. The operculum on the free, apical end resembles the cupule of an acorn in shape and even in pattern and color to some extent. The flange of the operculum is set down inside the collar-like opening of the egg shell. This opening is about .I $\mathrm{mm}$. in diameter. The operculum is circular with a flattened margin that looks somewhat alveolar. The center of the disc usually rises more or less sharply to a peak. The base of this little cone flares in a rather evenly diverging series of fine, radiating ridges. The shells are quite uniformly fuscous-amber and somewhat translucent except for the whitish alveolar rim of the operculum. The surface of the shell appears delicately reticulated when light strikes it from certain angles. These eggs are spaced closely, without touching, in circular or rather irregular patches on the underside of the willow leaf blade. The egg placement of this species bears no relationship to the leaf venation, which is not very prominent. The lower leaf surface is also sparsely hirsute. The axis of the egg is almost vertical to the leaf epidermis.

As the tables show, a leaf may bear as many as 420 eggs in four discrete patches. Since the willow leaves are relatively small (a pressed branchlet at hand is $23 \mathrm{~cm}$. long and has 18 leaves, the largest of which has a blade $10 \mathrm{~cm}$. long and $2.8 \mathrm{~cm}$. in maximum width), and since the adult lace bugs of this species seldom occur in large numbers on a single leaf here, single egg clusters are more frequent. Probably the females normally lay one hundred or more eggs at a time. Disturbance during oviposition may account for small clusters and the occasional egg laid singly. Eggs were noted as early as May 24th in 1957 and as late as August 3rd in 1958.

The willows locally have regularly been quite heavily infested 
Table I Eggs of Corythucha mollicula O. \& D. on Salix leaves in Bradford, Mass., June 24, 1957

Leaf No. Number of Eggs in Mass

a. b. c. d.

177

173

71

I 4

d.

Total

I

53

$\begin{array}{ll}4 & 253 \\ 5 & 106\end{array}$

$\begin{array}{ll}4 & 253 \\ 5 & 106\end{array}$

53
253

106
$3 \quad 178$

34

72

34

72

63

63

I 33

133

I 7

II 7

\section{Average: 154.5 eggs per leaf I06.25 eggs per mass}

The majority of these eggs had already hatched and some were just hatching at the time of preservation.

Table II Salix leaves with eggs taken from the same station on June 15,1958

Leaf No.

Number of Eggs in Mass
a.
b.
c.
d. 78

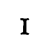
78
16
I
I7
I 5 I
I5 I
122
122
191
I9I
160
160
76
76
31
31
73
I9
92
I6I
7
7
176
Average: 109.4 eggs per leaf
I094 eggs
73 eggs per mass

Total 
with a small green chrysomelid beetle. Both the adult beetles and their grubs feed voraciously on the willow foliage. Both leaf \# 4 and \# IO in the 1958 series showed considerable chrysomelid damage. Tingid eggs in some numbers seem to be destroyed incidentally by their beetle competitors.

In these collections two specimens had parasites attached. The first was collected on July 28, 1957 with a white ovoid mite about $.2 \mathrm{~mm}$. wide and $.4 \mathrm{~mm}$. long clinging to the right side of the body under the elytron and above the leg base. It was attached at the joint between the metathorax and the abdomen.

There was a female lace bug in the collection for June 8, I958 with a grub-like, whitish parasite projecting from the right side of the abdomen. Dissection revealed that the parasite was about $.7 \mathrm{~mm}$. long and $.2 \mathrm{~mm}$. wide. It lay transversely in the abdomen of the host and about half of the parasite extended beyond the body wall of the lace bug in the pleural region. Lack of distinctive features made it impossible for me to identify.

Bailey, Norman S.

\section{Literature Cited}

1951. The Tingoidea of New England and their Biology. Entomologica Fernald, M. L. Americana, 31 (n.s.):1-140.

1950. Gray's Manual of Botany (Eighth Edition). American Book Company, Boston. 

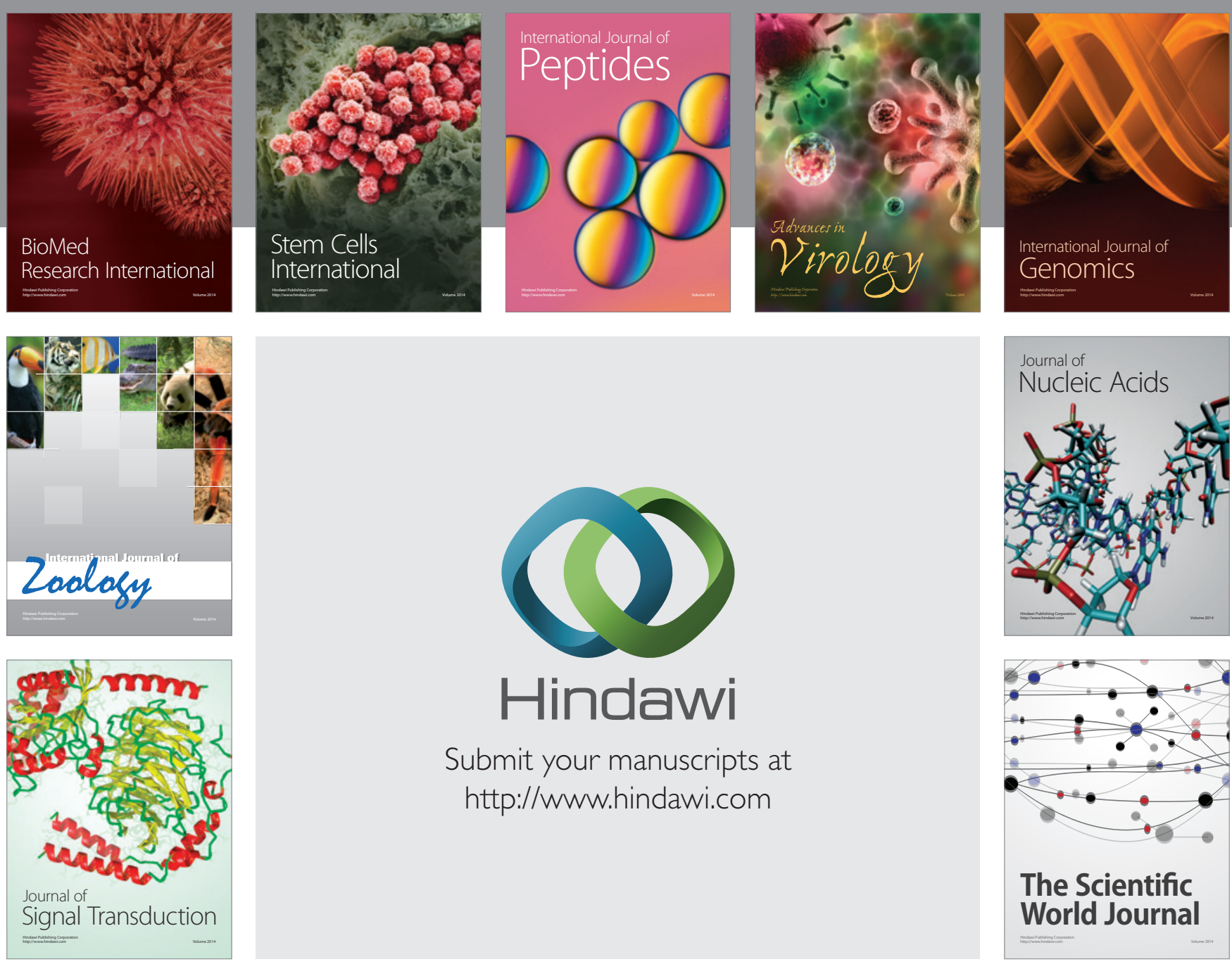

Submit your manuscripts at

http://www.hindawi.com
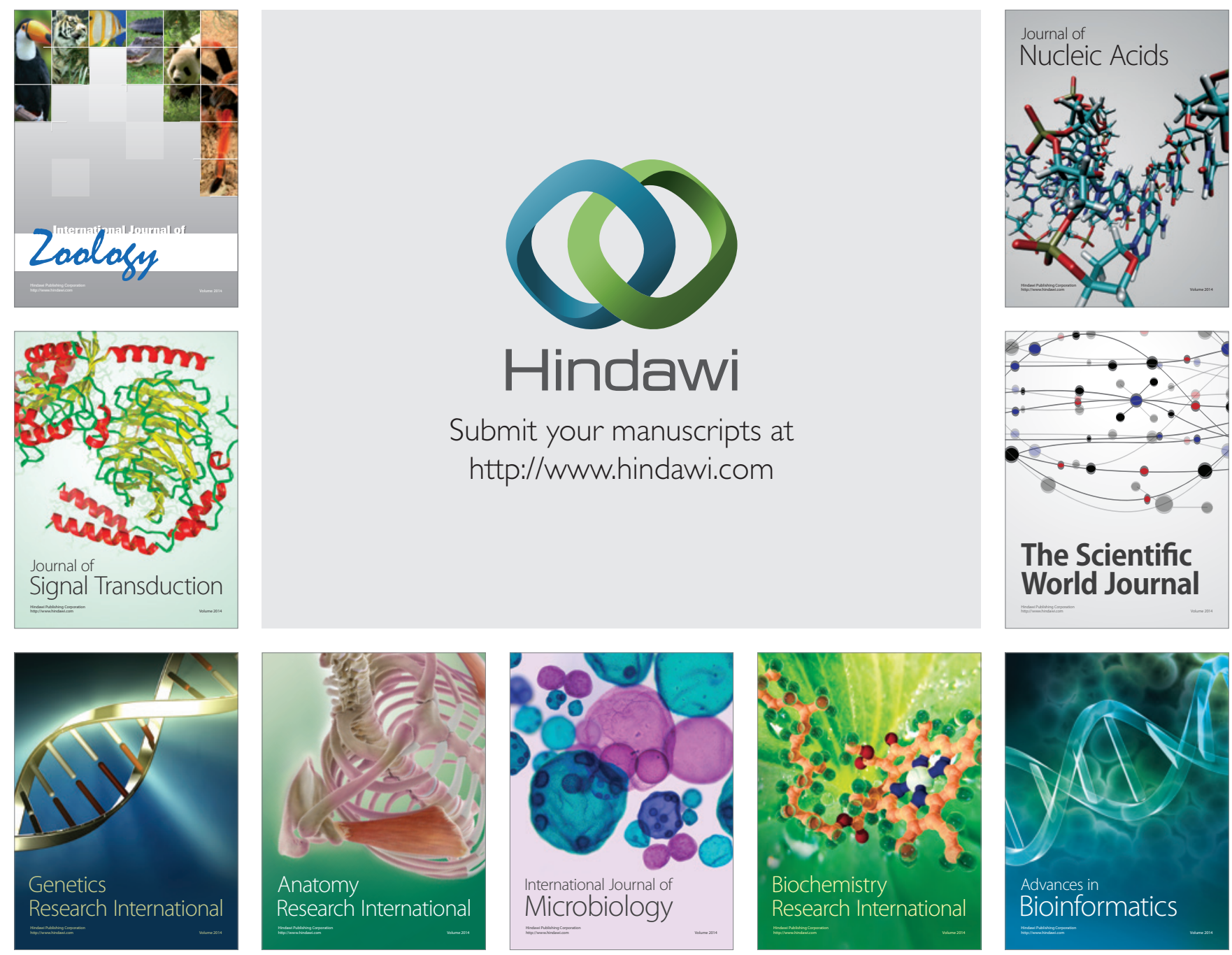

The Scientific World Journal
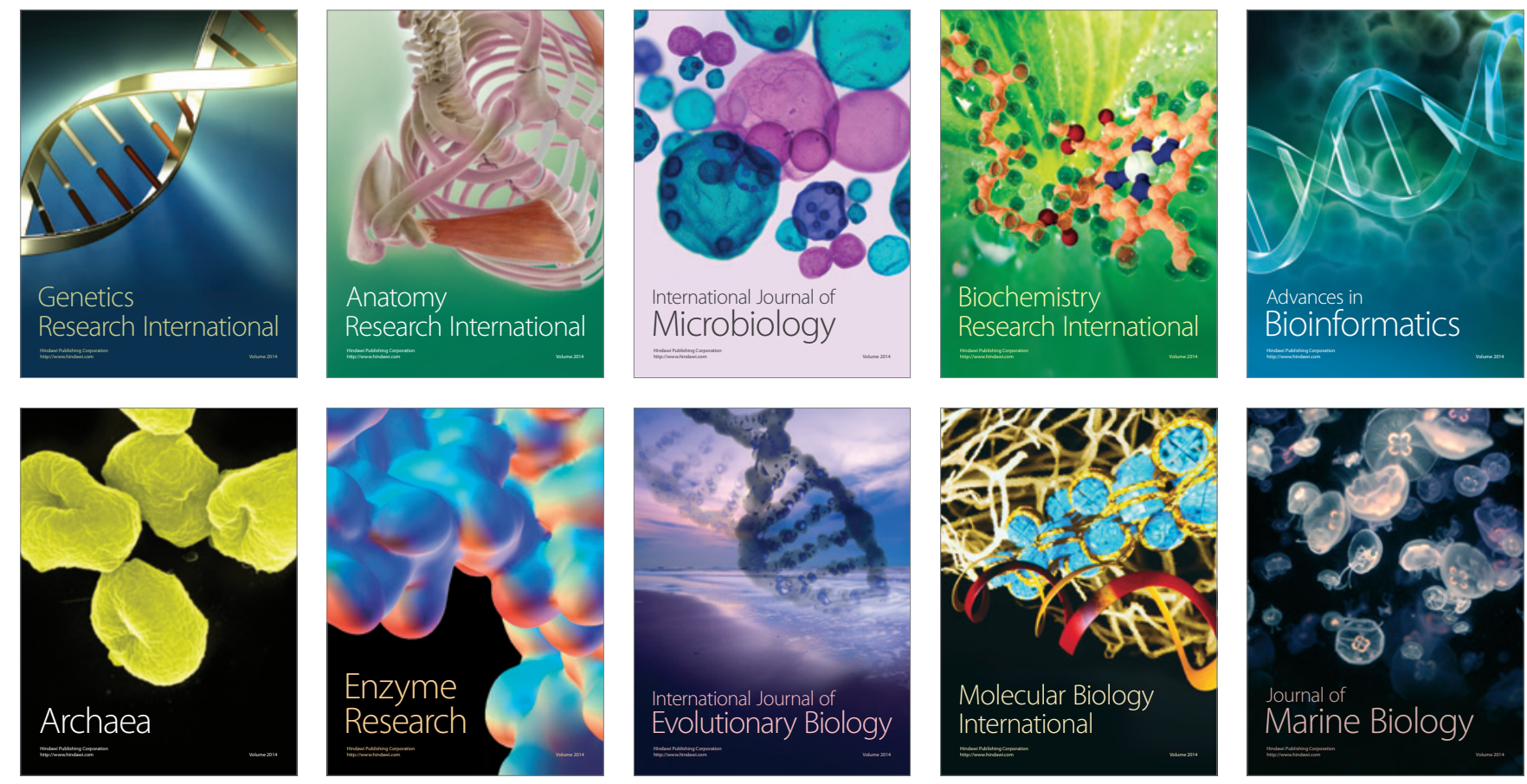